\title{
Cytotoxic Effect Of Five Medicinal Plants Extracts Using Brine Shrimp (Artemia salina) TEST
}

\author{
R. Akter*, Mohammed A. Satter, M. S. Khan, M. S. Rahman and N. U. Ahmed \\ Bangladesh Council of Scientific and Industrial Research (BCSIR), Chittagong-4220, Bangladesh
}

\begin{abstract}
Medicinal plants like Curcuma longa, Curcuma zedoaria, Streblus asper, Enhydra fluctunas and Scoparia dulcis are commonly available in Bangladesh. This study investigated the effect of ethanol extracts from these five medicinal plants on the viability of Brine Shrimp larvae. The lethal concentrations ( $\mathrm{LC}_{50}$ values) of the extracts were determined. $\mathrm{LC}_{50}$ values of $C$. longa, C. zedoaria and $S$. asper were less than $250 \mu \mathrm{g} / \mathrm{ml}$ and that of E. fluctunas was greater than $250 \mu \mathrm{g} / \mathrm{ml}$. Among five plants tested, one $(S$. dulcis) appear to be inactive. Results indicate that $C$. longa, C. zedoaria and $S$. asper could be potential sources of bio-active compounds.
\end{abstract}

Key words : Cytotoxicity, Crude plant extracts, Artemia salina, Curcuma longa, Curcuma zedoaria, Streblus asper, Enhydra fluctunas, Scoparia dulcis

\section{Introduction}

Modern pharmacologic medicine originally derived its medicines from medicinal plants, fungi, and microorganisms (Yarnell, 2000). On the basis of global survey data from 1997, about 119 plant-derived compounds of known structure are currently used as prescription drugs (Zhu et al., 1996; Zhu et al., 1997). More than half of currently available drugs (Newman and Cragg, 2007) are natural compounds or are related to them, and in the case of cancer this proportion surpasses 60\% (Gordaliza, 2007).

Curcuma longa L, is known as 'Holud or Haldi' in Bengal and turmeric in English. Powder of its rhizome is used for its flavoring, as a spice in both vegetarian and non-vegetarian curry preparations and it also has digestive properties. The fresh rhizome is used by the beauticians. Disorders, like anorexia, coryza, cough, diabetic wounds, hepatic disorder, rheumatism and sinusitis (Ammon et al., 1992) sprains and swellings caused by injury (Ammon and Wahl, 1991) are treated by different parts of the plant $C$. longa.

Rhizome of Curcuma zedoaria locally known as shoti, is used to make drinks. Hot water extract of the plant have shown moderate anti-mutagenic activity (Lee and Lin, 1988) as well as protective effect on d-galactosamine/ lipopolysaccharide- induced liver injury in mice (Matsuda et al., 1998).

Scoparia dulcis (English name sweet broom-weed) is known as misridana or cinigura in Bangladesh (Yousuf et al., 2009).
The plant is used for hypertension in Taiwan (Chow et al., 1974) and diabetes mellitus in India (Satyanarayana, 1969). Poor antifungal and good antibacterial property have also been attributed to the alcoholic extract of the plant $S$. dulcis (Anwar et al., 1994; Begum et al., 1993).

Streblus asper (known as Harba in Chittagong, Bnagladesh) has been used in fever, dysentery, relief of toothache, antigingivitis (Gaitonde et al., 1964) and insecticidal activity towards mosquito larvae (Kritsaneepaiboon, 1989). In Bangladesh it ( $S$. asper) is used in urinary inflammation and galactagogue (Yousuf et al., 2009).

Enhydra fluctuans (Bengali Name: Helencha) is used as a vegetable with fish curry in Bangladesh. Leaf paste is applied over head as a cooling agent and around the inflamed breast to reduce inflammation. The plant is rich in protein sterols (Krishnaswamy and Prasanna, 1975). $\quad \beta$-Carotene (Dewanji et al., 1993) and terpenes (Bohlmann et al., 1982) have been isolated from the plant.

There are several proven methods and protocols to study the biological activity and pharmacological properties of pure compound or a library of compounds. The in vivo lethality in a simple zoological organism, such as the brine shrimp lethality test (Meyer et al., 1982), might be used as a simple tool to guide screening and fractionation of physiologically active plant extracts, where one of the simplest biological responses to monitor is either dead or alive. The brine shrimp 
assay has been established as a safe, practical, and economic method for the determination of the bioactivity of synthetic compounds (Almeida et al., 2002) as well as plant products (Meyer et al., 1982; Lhullier et al., 2006; Stefanello et al., 2006) and in toxicological studies. Form this point of view, we selected five common medicinal plants of Bangladesh namely, S. dulcis (Bondhoni), E. fluctunas (Helencha), C. longa (Holud), C. zeoardia (Shothi) and S. asper (Sheora) for investigation of their cytotoxic effects using brine shrimp lethality assay.

\section{Collection of plant materials}

Five plants namely $C$. longa (rhizome), $C$. zedoaria (rhizome), S. dulcis (shoot), S. asper (leaves) and E. fluctuans (whole plant) were collected from plantation and residential area of BCSIR laboratories, Chittagong during February to November 2010 depending on availability. The plants were identified by Industrial Botany Research Division of BCSIR laboratories, Chittagong. Voucher specimens (CL-121, CZ122, SD-123, SA-124 and EF-125) were deposited in the herbarium of BCSIR Laboratory, Chittagong.

\section{Preparation of the crude extracts}

Fresh plant parts were washed, cut into pieces and shed dried at room temperature $\left(28 \pm 3^{\circ} \mathrm{C}\right)$ and ground into coarse powder and stored in an air tight container. Plant powders were macerated in pure ethanol (95\%) individually for 7 days at room temperature $\left(28 \pm 3^{\circ} \mathrm{C}\right)$ with occasional shaking. Every seven days later, ethanol extracts were filtered off through a cotton plug and then with a Whatman No. 1 filter paper. The extracts were concentrated under reduced pressure below $50^{\circ} \mathrm{C}$ through rotary vacuum evaporator (EYELA Rikakikai Co., Ltd., Tokyo). The concentrated extracts were collected in a petri dish and air dried at room temperature. The whole process was repeated three times for each plant. The concentrated extracts were stored at $4^{\circ} \mathrm{C}$ until use.

\section{Artemia salina hatching}

Brine shrimp (Artemia salina) eggs obtained locally (Red Jungle Brand, O.S.I., The great Salt Lake, USA.) were hatched in artificial salt water $(2.5 \%$ commercial $\mathrm{NaCl}$ sloution) at $\left(30 \pm 2^{\circ} \mathrm{C}\right), \mathrm{pH}$ between 7 and 8 and at constant illumination (2000 lux). The brine shrimp eggs were incu- bated in a hatching tank with a water height of $2.54 \mathrm{~cm}$. These hatching conditions correspond to the natural environment (shallow salt water). After an average one day from hatching, the shrimp larvae were used for the experimental bioassay. At this time the larvae still live on their own yolksac and received no further food during the experimental time. The living larvae have a high mobility. Nauplii were collected with a Pasteur pipette and kept for an additional 24 $\mathrm{h}$ under the same conditions to reach the metanauplii stage.

\section{Biological screening}

The samples to be assayed were dissolved in artificial seawater using Twin- 80 as emulsifying agent. Five milliliter of test solution with different concentrations $(10-80 \mu \mathrm{g} / \mathrm{ml}$ for $C$. longa extract) were taken in five different $25-\mathrm{ml}$ beakers for each sample. About 20 nauplii were added to each set of beakers containing the samples. Controls containing $1.0 \%$ Twin-80 in artificial seawater were included in each experimental set. Twenty-four hours later, the number of survivors was counted, recorded and the lethal concentration $50 \%$ ( $\mathrm{LC}_{50}$ value) and $95 \%$ confidence intervals were calculated by Probit analysis (Finney, 1971).

\section{Qualitative phytochemical screening}

The ethanolic extract was qualitatively tested for the presence of various phyto-constituents according to the methods described by Parekh and Chanda (2009). Tests for alkaloids performed with Mayer's and Hager's reagent, flavonoids with the use of ammonia and concentrated $\mathrm{H}_{2} \mathrm{SO}_{4}$ (Sofowara, 1993; Harbrone, 1973), glycoside with $\mathrm{NaOH}$ solution and frothing test was done for saponins.

\section{Results and Discussion}

Crude extracts and pure substances into toxic were classified into toxic $\left(\mathrm{LC}_{50}\right.$ value $\left.<1000 \mu \mathrm{g} / \mathrm{ml}\right)$ and non-toxic $\left(\mathrm{LC}_{50}\right.$ value $>1000 \mu \mathrm{g} / \mathrm{ml}$ ) according to reports of Meyer et al. (1982). In our test majority of the extracts (four out of five) showed good brine shrimp larvicidal activity. Ethanol extract of Curcuma longa was found to be highly effective $\left(\mathrm{LC}_{50}=\right.$ $26.63 \mu \mathrm{g} / \mathrm{ml}$ ) whereas Curcuma zedoaria and Streblus asper showed considerable action and their $\mathrm{LC}_{50}$ values were less than $250 \mu \mathrm{g} / \mathrm{ml}$ but that of Enhydra fluctunas was $332 \mu \mathrm{g} / \mathrm{ml}$ (Table I). Natural products play an important role in

Table I: Brine shrimp cytotoxicity of EtOH extracts of the plants

\begin{tabular}{l|c|c|c}
\hline Species & Part used & $\mathrm{LC}_{50}(\mu \mathrm{g} / \mathrm{ml})$ & $95 \% \mathrm{CI}(\mu \mathrm{g} / \mathrm{ml})$ \\
\hline Curcuma longa & Rhizome & 26.63 & $9-42$ \\
Curcuma zedoaria & Rhizome & 145.87 & $128-163$ \\
Scoparia dulcis & Shoot & $>1000$ & $201-31758$ \\
Streblus asper & Leaves & 224.74 & $75-676$ \\
Enhydra fluctunas & Whole plant & 332.45 & $272-394$ \\
\hline
\end{tabular}

CI: Confidence Interval 
chemotherapy (Pezzuto, 1997; Cragg, 1998; Lee, 1999; Schwartsmann, 2000). They offer valuable source of compounds with a wide variety of biological activities and chemical structures provide important prototypes for the development of novel drugs (Cragg, 1998; Verpoorte, 1998; Vuorela et al., 2004). This is also true for anti-cancer agents, most of which have been derived from natural sources; directly as pure native compounds, or as semi-synthetic analogs, or as models for synthetic compounds (Lindholm, 2005). The correlation between the brine shrimp lethality assay and in vitro growth inhibition of human solid tumor cell lines shows the value of this bioassay as a pre-screening tool for anti-tumor drug research (Anderson et al., 1991). Qualitative phytochemical analysis results (Table II) shows that all the plant extracts in this investigation possess one or different types of secondary metabolites (alkaloids, flavonoids, glycosides or explored for prospecting novel antibacterial, antifungal, anticancer leads.

\section{References}

Almeida P. A., Silva T. M. S. and Echevarria A. (2002). Mesoionic 5-alkyl- 1,3-dithiolium-4-thiolates: Synthesis and brine shrimp toxicity. Heterocycl. Comm. 8: 593-600.

Ammon H. P. T. and Wahl M. A. (1991). Pharmacology of Curcuma longa. Planta Medica. 57: 1-7.

Ammon H. P. T., Anazodo M. I., Safayhi H., Dhawan B. N. and Srimal R. C. (1992). Curcumin: a potent inhibitor of Leukotriene B4 formation in rat peritoneal polymorphonuclear neutrophils (PMNL). Planta Medica. 58: 26-28.

Table II: Results of phytochmical screening of the plants

\begin{tabular}{|c|c|c|c|c|c|}
\hline \multirow[t]{3}{*}{ Species } & \multicolumn{5}{|c|}{ Name of tests and results } \\
\hline & \multicolumn{2}{|c|}{ General test } & \multicolumn{2}{|c|}{ General test } & \multirow{2}{*}{$\begin{array}{c}\text { Frothing test } \\
\text { of Saponin }\end{array}$} \\
\hline & Mayer's & Hager's & Flavonoids & Glycosides & \\
\hline Curcuma longa & - & - & + & + & - \\
\hline Curcuma zedoaria & + & + & + & + & + \\
\hline Scoparia dulcis & - & - & - & + & + \\
\hline Streblus asper & - & - & - & + & + \\
\hline Enhydra fluctunas & + & + & - & + & + \\
\hline
\end{tabular}

$(+)$ : Present, (-): Not present

saponins). Many new natural compounds of diverse structures, isolated from plant sources (Lee, 1999; Mukherjee et al., 2001), have been considered prototypes, leads or heads of series and their later structural modification has afforded compounds with pharmacological activity and extraordinary therapeutic possibilities (Butler, 2004; Paterson and Anderson, 2005; Koehn and Carter, 2005). The brine shrimp bioassay results of $C$. longa, $C$. zedoaria, and $S$. asper clearly demonstrate the toxic effects of extracts, which could be due to any of the secondary metabolites (alkaloids, flavonoid, glycoside or saponin) of the plants. In toxicity assessment of plant extracts by brine shrimp bioassay, an $\mathrm{LC}_{50}$ value lower than $1,000 \mu \mathrm{g} / \mathrm{ml}$ is considered bioactive (Meyer et al., 1982). In our study all the extracts except $S$. dulcis, have $\mathrm{LC}_{50}$ values less than $1,000 \mu \mathrm{g} / \mathrm{ml}$; therefore, the rest of the four plant extracts can have bio-active secondary metabolites. Further work is required to isolate and characterize the individual bioactive compound.

\section{Conclusion}

The present findings suggested that the utilization of Curcuma longa powder in curry and in cosmetic might have some beneficial effect as well as Curcuma longa, Curcuma zedoaria, Streblus asper and Enhydra fluctunas could be
Anwar M. N., Singha P., Begum J. and Chowdhury J. U. (1994). Antifungal activity of some selected plant extracts on phytopathogenic fungi. Bang. J. Life Sci. 6(2): 23-26.

Begum J., Yusuf M., Chowdhury J. U. and Wahab M. A. (1993). Studies on essential oils for their antifungal and antibacterial properties. Part-1: Preliminary screening of 35 essential oils. Bangladesh J. Sci. Ind. Res. 28(4): 25-34.

Bohlmann F., Ahmed M., Robinson H., and King M. (1982) Melampolides from Enhydra fluctuans var. Fluctuans. Phytochemistry. 21(7): 1675-1678.

Butler M. S. (2004). The role of the natural product chemistry in drug discovery. J. Nat. Prod. 67: 2141-2153.

Chow S. Y., Chen S. M., Yang C. M. and Hsu H. (1974) Pharmacological studies on China herbs. (I) Hypotensive effect of 30 Chinese herbs. J. Form Med. Assoc. 73: 729- 739.

Cragg G. M. (1998). Paclitaxel (Taxol $\left.{ }^{\circledR}\right)$ : a success story with valuable lessons for natural product drug discovery and development. Medicinal Research Reviews. 18(5): 315-331. 
Dewanji A., Matai S., Si L., Barik S. and Nag A. (1993). Chemical composition of two semi-aquatic plants for food use. Plant Foods Hum. Nutr. 44(1): 11-16.

Finney D. J. (1971). Probit Analysis. Cambridge University Press. Cambridge.

Gaitonde B. B., Vaz A. X. and Patel J. K. (1964). Chemical and pharmacological study of root bark of Streblus asper. Ind. J. Med. Sci. 18: 191-199.

Gordaliza M. (2007). Natural products as leads to anticancer drugs. Clin. Transl. Oncol. 9: 767-776.

Harborne J. B. (1973). Phytochemical methods, London. Chapman and Hall, Ltd. pp. 49-188.

Koehn F. E. and Carter G. T. (2005). The evolving role of natural products in drug discovery. Nat. Rev. Drug Discov. 4: 206-220.

Krishnaswamy N. R. and Prasanna S. (1975). Clerosterol from Enhydra fluctuans, Phytochemistry. 14(7): 1663

Kritsaneepaiboon S. (1989). Effect of plant extracts on insects. Songklanagarin. J. Sci. Technol. 11: 107-112.

Lee H. and Lin J. Y. (1988). Antimutagenic activity of extracts from anticancer drugs in Chinese medicine. Mutation Research. 204: 229- 234.

Lee K. H. (1999). Novel antitumor agents from higher plants. Medicinal Research Reviews. 19: 569-596.

Lhullier C., Horta P. A. and Falkenberg M. (2006). Avaliação de extratos de macroalgas bênticas do litoral catarinense utilizando o teste de letalidade para Artemia salina. Rev Bras Farmacogn. 16: 158-163.

Lindholm P. (2005). Cytotoxic Compounds of Plant OriginBiological and Chemical Diversity. Ph.D. Thesis, Faculty of Pharmacy, Upsala University, Sweden. pp 14.

Matsuda H., Ninomiya K. and Yoshikawa M. (1998). Inhibitory effect and action mechanism of sesquiterpenes from Curcuma zedoaria rhizome on d-galactosamine/lipopolysaccharide-induced liver injury. Bioorganic \& Medicinal Chemistry Letters. 8: 339-344.

Meyer B. N., Ferrighi N. R., Putnam J. E., Jacobsen L. B., Nichols D. E. and McLaughlin J. L. (1982). Brine shrimp: A convenient general bioassay for active plant constituents. Planta Medica. 45: 31-34.

Mukherjee A. K., Basu S., Sarkat N. and Ghosh A. C. (2001). Advances in cancer therapy with plant based natural products. Curr. Med. Chem. 8: 1467-1486.
Newman D. J. and Cragg G. M. (2007). Natural products as sources of new drugs over the last 25 years. J. Nat. Prod. 70: 461-477.

Pezzuto J. M. (1997). Plant-derived anticancer agents. Biochemical Pharmacology. 53: 121-133.

Parekh J. and Chanda S. V. (2009) In vitro antimicrobial activity and phytochemical analysis of some Indian medicinal plants. Turkey J Bio. 31: 53-58.

Paterson I. and Anderson E. A. (2005). The renaissance of natural products as drug candidates. Science. 310: 451-453.

Satyanarayana K. (1969). Chemical examination of Scoparia dulcis (Linn): Part I. J. Indian Chem. Soc. 46: 765-766.

Schwartsmann G. (2000). Marine organisms and other novel natural sources of new cancer drugs. Annals of Oncology. 11: 235-243.

Stefanello M. E. A., Salvador M. J., Ito I. Y. and Macari P. A. T. (2006). Avaliação da atividade antimicrobiana e citotóxica de extratos de Gochnatia polymorpha ssp. fl occosa. Rev Bras Farmacogn. 16: 525-530.

Sofowara A. (1993). Medicinal plants and Traditional medicine in Africa. Spectrum Books Ltd, Ibadan, Nigeria. p. 289.

Verpoorte R. (1998). Exploration of nature's chemodiversity: the role of secondary metabolites as leads in drug development. Drug Discovery Today 3: 232-238.

Vuorela P., Leinonenb M., Saikkuc P., Tammelaa P., Rauhad J. P., Wennberge T. and Vuorela H. (2004). Natural products in the process of finding new drug candidates. Current Medicinal Chemistry. 11(11): 1375-1389.

Yarnell E. (2000). The botanical roots of pharmaceutical discovery. Alternative and Complementary Therapies. 6(3): $125-128$.

Yusuf M., Begum J., Hoque M. N. and Chowdhury J. U. (2009). Medicinal Plants of Bangladesh, 2nd ed. BCSIR Laboratories Chittagong. pp 599.

Zhu D. Y., Bai D. L. and Tang X. C. (1996). Recent studies on traditional Chinese medicinal plants. Drug Dev. Res. 39: 147-157.

Zhu D. Y., Bai D. L. and Tang X. C. (1997). Recent studies on traditional Chinese medicinal plants. Drug Dev. Res. 39: 147-157.

Received :May 11, 2011;

Accepted : August 08, 2011 